\title{
The Palynomorphological Characteristics of Galatella Albanica Degen (Aster Albanicus Degen ) (Asteraceae)
}

\author{
Anxhela Dauti ${ }^{1}$ \\ Gëzim Kapidani² \\ Blerina Pupuleku1 \\ Nikoleta Kallajxhiu ${ }^{1}$ \\ Admir Jançe ${ }^{3}$ \\ Silvana Turku ${ }^{1}$ \\ ${ }^{1}$ Department of Biology, Faculty of Natyral Sciences, University "A. Xhuvani", Elbasan, Albania \\ ${ }^{2}$ Department of Biology, Faculty of Natyral Sciences, University of Tirana, Tirana, Albania \\ 3 Albanian University, Tirana, Albania \\ Email: dauti.anxhela@yahoo.com
}

Doi:10.5901/ajis.2015.v4n2s2p196

\begin{abstract}
Galatella albanica Degen the synonym Aster albanicus Degen takes part in the tribe Astereae, subfamily Asteroideae (Asteraceae). It is an endemic specie of our country, Albania,but we can find them even in Kosove and in the south of Serbia. In Albania we find Galatella albanica Degen in dry and rocky places and a few in sandy places which have humidity (Durres Karavasta). This plant is studied even by the previous authors with the material taken from the rocky areas of Librazhdi and Shkopeti. The material for this study is taken fresh from the sandy places in the wood of Divjaka because of the aim of this study is to see if the ecologic factor affects on the pollen grains of this plant. According to the results of this study, the pollen grains of Galatella albanica Degen are tricolporate. In ecuatorial view the shape of pollen grains is elliptic to circular, while in polar view the shape is circular to triangular. The exine has an echinate sculpture and it has two-layer.
\end{abstract}

Keywords: Galatella, pollen grains, exine, echinate.

\section{Introduction}

Galatella albanica Degen is part of subfamily Asteroideae, tribe Astereae, family Asteraceae. Tribe Astereae includes 170 genera and 3000 species. Astereae is the second largest tribe after Senecioneae in the family Asteraceae (Funk at all, 2009). Galatella albanica Degen is the synonym of Aster albanicus Degen. This new naming of Aster albanicus is recommended in 2014 by ARS Systematic Botanists (GRIN).

In a study on the organogenesis in vitro of Aster albanicus Degen, Qendro is expressed that this specie consists of two subspecies, Aster albanicus Degen: subsp. paparistoi Qosja, that grows in sandy areas of the Adriatic coast in the pine forests and Aster albanicus albanicus that grows on serpentine rocks and is widespread in Bosnia and in Kosova. (Qendro, 2015)

Galatella albanica is involved with the naming Aster albanicus in the List of rare, threatened and endemic plants of Europea (BHL, 1983) and in the Red list of threatened plants (IUCN, 1997) where is presented and its distribution in Albania and Yugoslavia, now Serbia and southwest Kosova (Millaku et al., 2008).

In the palynological literature of Asteraceae the pollen grains of Galatella (Aster) included in a group called Aster tripolium type (Punt. Hoen, 2009). This group of Aster type is a combination of Aster type proposed by Erdtman (1961) and Van den Assem (1968, internal report) and Eupatorium type by Stix (1960). The description by Stix (1960) of Eupatorium type fits very well with today's Aster tripolium type. Fægri et al. (1989) included many of the pollen grains of Aster tripolium type at Solidago type. Moore et al. (1991) and also Valdés et al.(1987) combined pollen grains of a large number of genera at Aster type and Senecio vulgaris type as example Bidens, Gnaphalium, Senecio, Tussilago. Beug 
(2004) included the pollen grains of Aster, Bellis, Eupatorium, and Solidago at Senecio -Type.

In this paper presented morphological description of pollen grains of Galatella albanica Degen (Aster albanicus Degen) and also compare them with pollen grains to Aster albanicus Degen collected in serpentine ultrabasic rocks in Librazhd and Shkopet (Turku, 2013).

The palynological study of this specie is a fragment of the study about the palynomorphological characteristics of general members in Asteraceae family in our country, Albania (Dauti, 2013), (Dauti, 2014), (Dauti, 2014), (Kapidani, 1996).

In order to accomplish the quantitative analysis of palynomorphological features, 31 pollen grains are taken in consideration. For the study of pollen grains is used light microscope Motic B1 series. The measurements are performed with 400X power and the photos are taken with 1000X power.

\section{Material and methods}

The material for the study was obtained in National Herbarium in Tirana. To achieve the study of pollens' morphological characteristics we have used three analytical methods.

Acetolysis of Erdtman method (Erdtman, 1960)

Acetolysis of Avetisjan method (Avetisjan, 1950)

Basic fuchsine method of Smoljaninov, Gollubkov (Smoljaninova \& Gollubkova, 1967)

The fixing of pollen grains is made with glycerin gelatin prepared according to Kisser method (Sllatkov, 1967) The palynomorphological dates in this study regard the material acetolysed. The terminology is based on that recommended previously Erdtman (1952), Punt et al. (,1994) and Kapidani, ( 2005).

\section{Results and discussion}

\subsection{Morphological description of pollen grains}

\subsubsection{Galatella albanica Degen (synonym Aster albanicus Degen)}

Herbaceous and perennial plant with purple flowers. In dry and rocky areas, mainly ultrabasic (200-2100) and less in coastal sand areas a little more humid (Durres- Karavasta). August-november. Fig. 1 (Vangjeli at al, 2000)

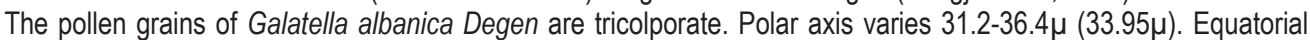
diameter varies $31.2-36.4 \mu(34.66 \mu)$. The shape of pollen grains by outline presented oblate spheroidal in prolate spheroidal P/E $=0.93-1.08$.

Exine is thick and two-layer with echinate sculpture. Endexine and ectexine are almost equal. Thickness exine with spines varies 5-7.28 $\mu(5.5 \mu)$. The spines are conical and acuminate. The length of spines $3-5 \mu(3.5 \mu)$ and their width in

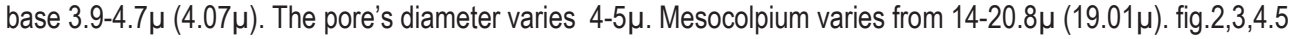

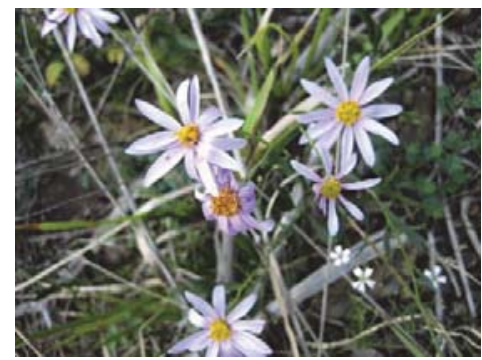

Fig. 1: Galatella albanica Degen (Aster albanicus Degen) 


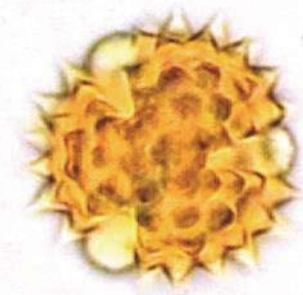

Figure 2 Polar view (1000X)

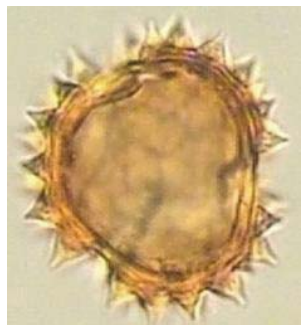

Figure 4 Polar view (1000X)

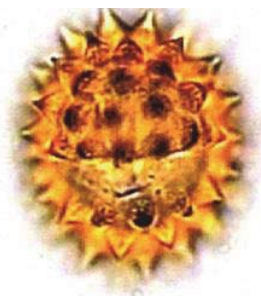

Figure 3 Equatorial view (1000X)

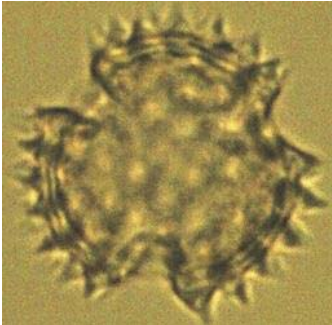

Figure 5 Polar view (1000X)

On the table below presents the palynomorphological data to Galatella albanica Degen by countries where it is collected.

Table 1. The palynomorphological data of Galatella albanica Degen Divjake, Librazhd, Shkopet.

\begin{tabular}{|l|c|c|c|}
\hline Features taken in study & Galatella albanica Divjake & $\begin{array}{c}\text { Galatella albanica Librazhd } \\
\text { (Turku. 2007) }\end{array}$ & $\begin{array}{c}\text { Galatella albanica Shkopet } \\
\text { (Turku. 2007) }\end{array}$ \\
\hline Polar axis (P) & $31.2-36.4 \mu(33.95 \mu)$ & $27.5-32.6 \mu(29.4 \mu)$ & $24.9-32.2 \mu(28.7 \mu)$ \\
\hline Equatorial diameter $(\mathrm{E})$ & $31.2-36.4 \mu(34.66 \mu)$ & $27.5-32.6 \mu(29.4 \mu)$ & $24.9-32.2 \mu(28.7 \mu)$ \\
\hline Diameter of pore & $4-5 \mu(4.9 \mu)$ & $4.3-7.8 \mu(5.2 \mu)$ & $3.5-6.3 \mu(4.6 \mu)$ \\
\hline Thickness exine (with spines) & $5-7.28 \mu(5.5 \mu)$ & - & - \\
\hline Thickness exine (without spines) & $2 \mu$ & $1.8-2.7 \mu(2.3 \mu)$ & $1.8-2.2 \mu(2.0 \mu)$ \\
\hline Length of spines & $3-5 \mu(3.5 \mu)$ & $2.3-2.9 \mu(2.5 \mu)$ & $1.8-2.5 \mu(2.1 \mu)$ \\
\hline Width of spines & $3.9-4.7 \mu(4.07 \mu)$ & $2.0-2.7 \mu(2.4 \mu)$ & $1.6-2.2 \mu(2.0 \mu)$ \\
\hline
\end{tabular}

\section{Conclusions}

From the data of the table above noted a difference between Galatella albanica Degen collected in Divjake and what we collected in Librazhd and Shkopet in some of the palynomorphological features which are:

- Polar axis appears greater in Galatella albanica collected in Divjaka than in two other cases.

- Equatorial diameter also presented with greater at plant collected in Divjaka than two other cases, in which the equatorial diameter and polar axis are the same.

- Diameter of pore and thickness of exine not have any big fluctuations in value in three cases.

- Length of spines and their width in base of plant taken in Divjaka presented in values higher than in the two other cases.

From the results obtained in this study we see that the difference between the pollen grains of

Galatella albanica Degen collected at Divjaka with those collected in Librazhd and Shkopet. So we can say that the ecological factor, which in this case is the difference between the sandy soil and humidity in Divjaka and the serpentine rocky and ultrabasic in Librazhd and Shkopet, has affected to the palynomorphological features of Galatella albanica Degen. 


\section{References}

Avetisjan, B. M. (1950). Uproshennij acetolinij metod obrabotniki pilci. Bot. Zhurnal. T. 35, N 4, Fq. 385 - 386.

Beug, H.J. (2004). Leitfaden der Pollenbestimmung für Mitteleuropa und angrenznde Gebiete. Verlag Dr. Friederich Pfeil - München, 542 pp.

BHL. (1983). List of rare, threatened and endemic plants of Europe. (edic. 1982)

Dauti, A. Kapidani, G. Pupuleku, B. Kallajxhiu, N. Jance, A. (2013). Te dhenat palinomorfologjike te gjinise Pulicaria Gaertner. Buletini Shkencor, Seria e Shkencave te Natyres UNIEL: 119- 129.

Dauti, A. Kapidani, G. Pupuleku, B. Kallajxhiu, N. Jance, A. (2014). The palynomorphological characteristics of Anthemis in Albania. Albanian Journal of Agricultural Sciences (AJAS) Volume 13: Fq. 95- 99.

Dauti, A. Kapidani, G. Pupuleku, B. Kallajxhiu, N. Jance, A. Turku, S. (2014). The palynomorphological characteristics of Tanacetum in Albania. International Journal of Ecosystems and Ecology Sciences (IJEES) Volume 4/3: Fq. 445- 450.

Erdtman, G. (1952). Pollen Morphology and Plant Taxonomy of Angiosperm. Almquist and Wiksell, Stockholm. 553.

Erdtman, G. (1960). The Acetolysis Method. A revised description. Svensk Bot. Tidskar 54: 561-564.

Erdtman, G. Berglund, B. \& Praglowski, J. (1961). An Introductionto a Scandinavian Pollen Flora, Grana Palynologica, 2:3, 3-86

Fægri, K. Kaland, P.E. and Krzywinski, K. (1989). Textbook of Pollen Analysis. Wiley, Chischester, 4th ed., 328 pp.

Funk, V. A. Susanna, A. Stuessy, T. F. \& Bayer, R. J. (2009). Systematics, Evolution, and Biogeography of Compositae. International Association for Plant Taxonomy: Vienna.

GRIN Taxonomy for Plants. (2014). Name verified on: 10-Dec-2014 by ARS Systematic Botanists. Last updated: 10-Dec-2014 .

IUCN. (1997). Red list of Threatened plants 1997

Kapidani, G. (1996). Bazat e Palinologjisë. - Sejko Infoservis, Elbasan: 230

Kapidani, G. (2005). Fjalori i terminologjise palinologjike, Elbasan.

Millaku at al. (2008). Endemic, steno-endemic and relict plants in serpentines of Kosova.Sauteria 16, 2008.149-162

Moore, P.D. Webb, J.A. and Collinson, M.E. (1991). Pollen Analysis. Second Edition. Blackwell Scientific Publishers, Oxford, 216pp.

Punt, W. Blackmore, S. Nilsson, S. Le Thomas, A. (1994). The glossary of pollen and spore terminology. LPP Foundation, Utrecht.

Punt, W. Hoen, P.P. (2009). Asteraceae - Asteroideae, The Northwest European Pollen Flora, 69, Review of Palaeobotany and Palynology Volume 157, pp 22-183

Qendro, A. (2015). Studimi i organogjenezës in vitro për dy subspeciet e Aster albanicus Degen me qëllim ruajtjen e gjermoplazmës.

Sllatkov, A.N. (1967). Morfologiapilci i sporsovremnihrasteni V. SSSR Moskva Smolianinova L. A., Gollubkova, V. F. (1967). K metodikeissledovaniapilci. Dok. Ak. Nauk. SSSR T.L XXXVIII. 3. 125-126.

Stix, E. (1960). Pollenmorphologische Untersuchungen an Compositen. Grana Palynol., 2(2), 41-114 pp.

Turku, S. (2007). Studimi kromozomik në disa lloje të florës spontane në Shqipëri. Disertacion. 72-81pp

Valdés, B. Díez, M.J. and Fernández, I. (1987). Atlas polinico de Andalucia Occidental. Universidad de Sevilla Excma. Diputacionde Cadiz, 450 pp.

Van den Assem, A. (1968). Pollenmorfologie van de Asteraceae Tubuliflorae van Nederland. Internal report, 29 pp.

Vangjeli, J. Ruci, B. Mullaj, A. Paparisto, K. and Qosja, Xh. (2000). Flora e Shqipërisë. Vol. 4. - Tiranë. 